\title{
Odonata fauna of Sri Lanka: research state and threat status
}

\author{
Matjaž Bedjanič \\ Kolodvorska 21b, SI-2310 Slovenska Bistrica, Slovenia. \\ $<$ matjaz.bedjanic@guest.arnes.si>
}

Key words: Odonata, dragonfly, IUCN Red List, endangered species, conservation, Sri Lanka.

\begin{abstract}
Altogether 116 odonate species are known from Sri Lanka. The level of endemism is high - 53 taxa or $45.7 \%$ are confined to the island. The Chlorocyphidae, Euphaeidae, Protoneuridae, Platystictidae, Gomphidae and Corduliidae consist of almost exclusively endemic taxa. The odonate fauna of Sri Lanka is still insufficiently known. Knowledge on distribution, biology and taxonomy of adults and especially larval forms is very poor. An assessment of threat status showed that it is very endangered due to habitat destruction. A list of 47 endangered odonate taxa has been compiled. It consists of exclusively endemic taxa and comprises more than $80 \%$ of described species confined to the island. Altogether 20 species are preliminary put in the IUCN categories 'extinct' (EX) and 'critically endangered' (CR) and are urgently proposed for inclusion in the IUCN Red List. Future odonatological research priorities and recommendations are given. Special attention should be devoted to the work dealing with taxonomy of larval forms and adults. Serious faunistic mapping should cover the whole island and should be focused on still preserved areas. Simultaneously also the research of biology of selected species and research of seasonal phenology of adult Odonata should be carried out. Effective nature conservation measures in declared protected areas as well as the establishment of new protected areas and corridors in the Wet zone is of biggest importance for effective long-term preservation of a rich endemic fauna and flora of Sri Lanka, including odonates.
\end{abstract}

\section{SHORT GEOGRAPHIC OUTLINE}

The pear-shaped island of Sri Lanka - or formerly Ceylon - has an area of nearly $66,000 \mathrm{~km}^{2}$ and is a detached part of the continental Indian plateau of ancient crystalline rocks. It is situated between longitudes $79^{\circ} 39^{\prime}$ and $81^{\circ} 53$ ' $\mathrm{E}$ and latitudes $5^{\circ} 54^{\prime}$ and $9^{\circ} 52^{\prime} \mathrm{N}$. The relief of Sri Lanka may be subdivided into three peneplains with average altitudes of $30 \mathrm{~m}, 500 \mathrm{~m}$ and 1,500-1,800 m. The latter two peneplains form the Central Highlands, a complex of plateaus, mountain chains, massifs and basins in the southern half of the island. The highlands are surrounded by vast 
plains, which extend from the coast inland and rise to $100-150 \mathrm{~m}$ above sea level. As far as the climate of Sri Lanka is concerned, there are only slight variations in temperature, air humidity and day length. The island is commonly subdivided into two climatic subregions, referred to as the Dry and Wet zones. The Wet zone has a typical rainforest climate and there is always some rain. In June, July and August the south-west monsoon greatly affects the climate in the south-western and the central part of the island, while the north-eastern monsoon in December, January and February brings rain to the north-eastern lowland of the dry zone and minor parts of the adjoining central highlands. The average annual rainfall thus varies from more than $5,000 \mathrm{~mm}$ in the tropical south-western part of the island to about $1,000 \mathrm{~mm}$ on the north-west coast. Because of the very strong evaporation and seasonal rainfalls, a considerable part of the Dry zone suffers from drought and depends on artificial water storage for cultivation. For this purpose, especially in the Dry zone, over 12,000 irrigation reservoirs, which vary from $10-7,000$ ha and cover an area of over 175,000 ha, have been created.

With more than $50 \%$ forest cover in the 1950 s Sri Lanka was well above the world average and above the average for the Asian countries. In the end of the 1980 s the figure was only slightly over $20 \%$ of 'natural' forest cover, what amounts between $12,000-17,000 \mathrm{~km}^{2}$. Relatively large continuous patches of dry lowland forest are still left in the north-western, north-eastern and south-eastern parts of the island. In the contrary, the biologically and also odonatologically most interesting wet zone, which measures $22,500 \mathrm{~km}^{2}$, has only $9 \%$ of the surface covered by natural rainforests. Out of that only about $445 \mathrm{~km}^{2}$ are thought to be undisturbed, what represents only $2 \%$ of the original extent (Mittermeier et al. 2000).

\section{STATE OF THE ART}

\section{An overview of past odonate research}

The odonatological research in Sri Lanka has a very long tradition. The very first contribution to the knowledge of the island's Odonata was made by E. de SelysLongchamps and H.A. Hagen in the middle of the 19th century. Although their work has been continued by several recognized odonatologists, e.g. B.W.F. Kirby, F.F. Laidlaw, F.C. Fraser, M.A. Lieftnick and D. St. Quentin, in the last years it became very clear that our knowledge of the odonate fauna of Sri Lanka is still very incomplete.

Famous odonate manuals published by Fraser $(1933 c, 1934,1936)$ are still very relevant for the odonatological research in Sri Lanka. However, it has to be mentioned that Sri Lanka is one of the few Asian countries, which have a book on its odonate fauna - titled "Dragonflies of Sri Lanka" (Fonseka 2000). It represents a first and comprehensive overview of many different odonatological aspects, ranging from history of odonatological research, compilation of the known species descriptions, determination keys for adults and larvae, summary of distributional records, notes on ecology, etc. Despite some deficiencies and gaps it represents an important milestone in odonatological research in Sri Lanka and will surely stimulate further work on the topic. 
For the past nine years I was involved in the study of odonate fauna of Sri Lanka as this was the main subject of my graduation thesis (Bedjanič 1998). In this work all published information on each particular odonate taxon has been systematically gathered and together with the results of my fieldwork in January and February 1995 compiled to a synopsis of the odonate fauna of Sri Lanka. In this way an analysis of the present knowledge of the odonate fauna of Sri Lanka as well as a preliminary analysis of adult odonate phenology was made possible. After 1995, additional fieldwork was carried out in October-November 2001 as well as in April-May 2003 and some articles on the topic were published (Bedjanič 1999, 2000, 2001, 2002a; Bedjanič \& Şalamun 2002).

\section{Research state of odonate fauna}

According to the present knowledge altogether 116 Odonata species from 12 families occur in Sri Lanka. Zoogeographical analysis of the odonate fauna of Sri Lanka shows similarity with that of South India. However, 53 taxa $(45.7 \%)$ are confined to the island. The percentage of endemism is very high in the families Chlorocyphidae, Euphaeidae, Platystictidae, Protoneuridae, Gomphidae and Corduliidae (Fig. 1). More than half of all endemic species show no near relation to south Indian taxa. Some species, viz Sinhalestes orientalis, Anisogomphus solitaris, Cyclogomphus gynostylus and Microgomphus wijaya seem not to have any known near allies and are taxonomically isolated. During my research carried out in 2001 and 2003 at least four new endemic species were discovered. They will be described in near future, however, with the exception of Table 2 they are left out of consideration in the present article.

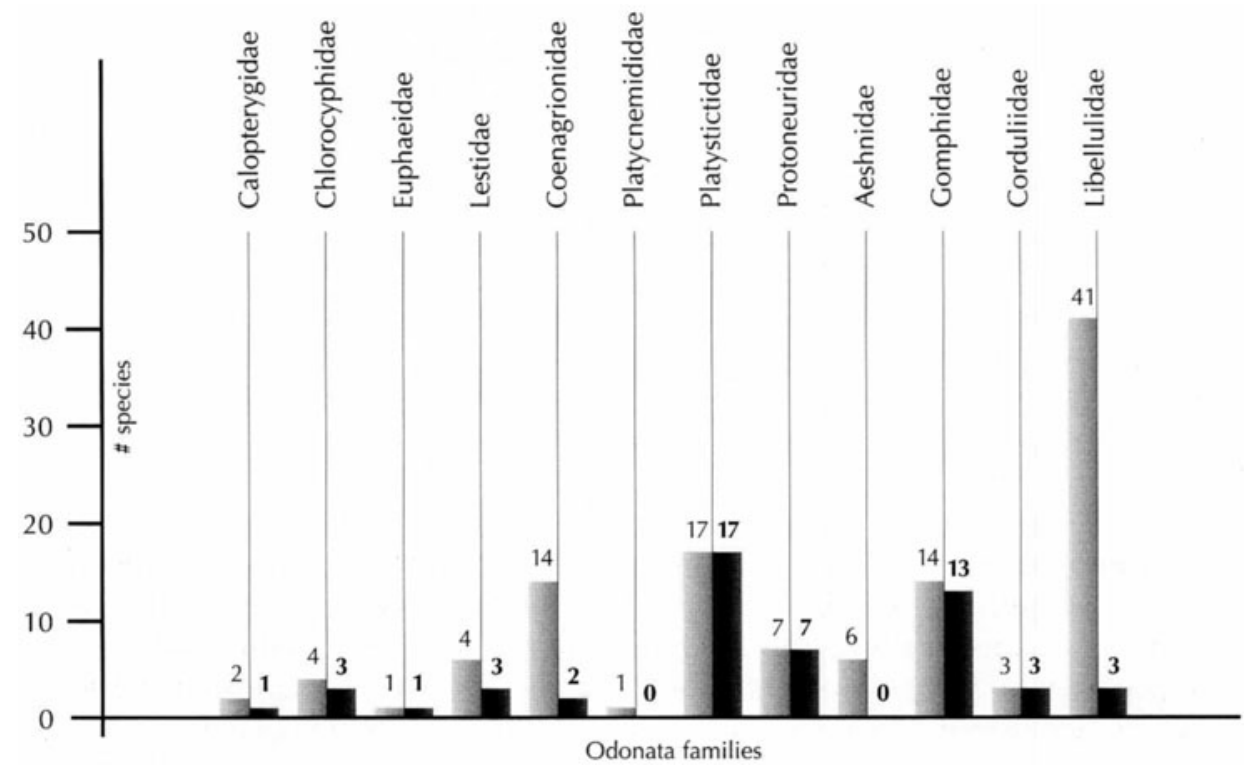

Figure 1: Endemism of the Odonata fauna of Sri Lanka. Total number of odonate species (grey columns) and number of endemic species (black columns), sorted by families. 
To gain a better overview of the present knowledge of odonate fauna of Sri Lanka the published data for all species and subspecies were analysed in order to evaluate their research state and arranged in different categories (Table 1). Practically all species in the given categories are confined to Sri Lanka and this fact definitely has also 'global' importance from the biodiversity conservation point of view. The following comments relate to the categories in Table 1 ; unpublished results of my research carried out in October-November 2001 as well as in April-May 2003 are not considered:

Category I: The group of the species in which one sex has not been described jet consists of only endemic taxa. Mostly the females are still undescribed - they are not so often seen at waters, their behaviour is less known, they are taxonomically insufficiently known and therefore difficult to determine.

Category II \& III: About one quarter of the species which occur in Sri Lanka has been found on only a few localities and the records were documented only by a very limited number of specimens. Also this category consists of exclusively endemic taxa. This information clearly indicates very poor faunistical research state of odonate fauna of Sri Lanka and in some cases should not be interpreted as actual rareness of the species.

Category IV: To the group of species in which larval stages or exuviae have not been described jet, not less than 70 species and subspecies or $60.3 \%$ of the odonate fauna of Sri Lanka can be designated. This information is very important since records of larvae and exuviae clearly indicate the development of the species in particular habitat. For the research of ecological requirements of individual species, which forms a basis for the effective species conservation measures, the correct determination of larvae or exuviae is of crucial importance.

Category V: Some species, e.g. Sinhalestes orientalis, Heliogomphus ceylonicus and $H$. nietneri, have not been found since their description, for more than 120 years. All species in this category are very rare and endangered or even extinct and deserve special attention in the future.

From the above analysis the following important conclusions can be made:

The odonate fauna of Sri Lanka is insufficiently known.

The fact, that almost $65 \%$ or 75 species and subspecies are included in at least one category is self-explaining.

As far as Odonata are concerned the special attention in the future should be devoted to projects dealing with taxonomy of larval forms and adults in direct connection with serious faunistic mapping.

In whole South and South-east Asia more attention should be devoted to the description of larval forms and exuviae. At the moment not a single zygopteran larval form of mostly endemic Sri Lankan representatives of the families Chlorocyphidae, Lestidae, Platystictidae and Protoneuridae is known. With the exception of St. Quentin (1973) who, however, gives only little taxonomy data, not a single article, dealing with the odonate fauna of the island is focused on larval forms. The available descriptions that can be found in Fraser (1933b) Lieftinck $(1940,1971)$ and Bedjanič (2000) are summarized by Fonseka (2000). They have to be therefore considered as more or less accidental. 
Table 1. Research state of the Odonata fauna of Sri Lanka. In each category the number of taxa and their proportion to all taxa known for Sri Lanka is given. All species, except those with an asterisk, are endemic to the island. - Category I: Species in which male or female are undescribed so far: 14 taxa; 12.1\%; II: Species with max. 10 known adult specimens: 27 taxa; 23.3\%; III: Species known from maximal three localities: 30 taxa; 25.9\%; IV: Species still lacking description of larval stages or exuvia: 70 taxa; $60.3 \%$; V: Species not found for more than 50 years: 16 taxa; $13.8 \%$.

\section{Family/species}

Chlorocyphidae

\begin{tabular}{|cccccc|}
\hline Libellago adami Fraser, 1939 & 0 & 0 & 0 & $\bullet$ & 0 \\
\hline finalis (Hagen, 1869) & 0 & 0 & 0 & $\bullet$ & 0 \\
\hline greeni (Laidlaw, 1924) & 0 & 0 & 0 & $\bullet$ & 0 \\
\hline lineata indica (Fraser, 1928) & 0 & 0 & 0 & $\bullet$ & 0 \\
\hline
\end{tabular}

Lestidae

\begin{tabular}{|c|c|c|c|c|c|}
\hline Indolestes divisus (Hagen, 1862) & 0 & 0 & 0 & - & 0 \\
\hline gracilis gracilis (Hagen, 1862) & O & 0 & O & $\bullet$ & O \\
\hline Lestes elatus Hagen, $1862^{*}$ & 0 & 0 & 0 & $\bullet$ & 0 \\
\hline malabaricus Fraser, $1929^{*}$ & 0 & 0 & 0 & $\bullet$ & 0 \\
\hline praemorsus decipiens Kirby, $1894^{*}$ & 0 & 0 & 0 & $\bullet$ & 0 \\
\hline Sinhalestes orientalis (Hagen, 1862) & 0 & $\bullet$ & $\bullet$ & $\bullet$ & $\bullet$ \\
\hline \multicolumn{6}{|l|}{ Coenagrionidae } \\
\hline Aciagrion occidentale Laidlaw, 1919* & 0 & 0 & 0 & $\bullet$ & 0 \\
\hline Ceriagrion cerinorubellum (Brauer, 1865)* & 0 & O & O & $\bullet$ & O \\
\hline Enallagma parvum Selys, $1876^{*}$ & 0 & 0 & 0 & $\bullet$ & 0 \\
\hline Mortonagrion ceylonicum Lieftinck, 1971 & $\bullet$ & $\bullet$ & $\bullet$ & $\bullet$ & O \\
\hline Onychargia atrocyana Selys, $1865^{*}$ & 0 & 0 & 0 & $\bullet$ & 0 \\
\hline Paracercion malayanum (syn. Cercion) (Selys, 1876)* & O & O & ० & $\bullet$ & 0 \\
\hline Pseudagrion malabaricum Fraser, $1924^{*}$ & 0 & 0 & 0 & $\bullet$ & 0 \\
\hline rubriceps ceylonicum (Kirby, 1891) & 0 & O & o & $\bullet$ & O \\
\hline \multicolumn{6}{|l|}{ Platystictidae } \\
\hline Drepanosticta adami (Fraser, 1933) & 0 & $\bullet$ & $\bullet$ & - & $\bullet$ \\
\hline austeni Lieftinck, 1940 & O & $\bullet$ & $\bullet$ & $\bullet$ & $\bullet$ \\
\hline brincki Lieftinck, 1971 & 0 & $\bullet$ & $\bullet$ & $\bullet$ & 0 \\
\hline digna (Selys, 1860) & O & 0 & $\bullet$ & $\bullet$ & O \\
\hline fraseri Lieftinck, 1955 & $\bullet$ & $\bullet$ & $\bullet$ & $\bullet$ & 0 \\
\hline hilaris (Hagen, 1860) & 0 & $\bullet$ & $\bullet$ & $\bullet$ & $\bullet$ \\
\hline lankanensis (Fraser, 1931) & 0 & 0 & 0 & $\bullet$ & 0 \\
\hline montana (Hagen, 1860) & 0 & $\bullet$ & $\bullet$ & $\bullet$ & $\bullet$ \\
\hline nietneri (Fraser, 1931) & 0 & 0 & 0 & $\bullet$ & 0 \\
\hline sinhalensis Lieftinck, 1971 & $\bullet$ & $\bullet$ & $\bullet$ & $\bullet$ & O \\
\hline starmuehlneri St. Quentin, 1972 & $\bullet$ & $\bullet$ & $\bullet$ & $\bullet$ & 0 \\
\hline submontana (Fraser, 1933) & $\bullet$ & $\bullet$ & $\bullet$ & $\bullet$ & $\bullet$ \\
\hline subtropica (Fraser, 1933) & 0 & 0 & $\bullet$ & $\bullet$ & 0 \\
\hline tropica (Hagen, 1860) & 0 & 0 & 0 & $\bullet$ & O \\
\hline walli (Fraser, 1931) & 0 & - & $\bullet$ & $\bullet$ & 0 \\
\hline Platysticta apicalis Kirby, 1894 & O & O & O & $\bullet$ & O \\
\hline maculata Hagen, 1860 & 0 & 0 & 0 & $\bullet$ & 0 \\
\hline
\end{tabular}




\section{Family/species}

category: I II III IV V

Protoneuridae

\begin{tabular}{|c|c|c|c|c|c|}
\hline Disparoneura ramajana Lieftinck, 1971 & - & ○ & - & - & $\mathrm{O}$ \\
\hline Elattoneura bigemmata Lieftinck, 1971 & 0 & 0 & $\bullet$ & $\bullet$ & 0 \\
\hline caesia (Hagen, 1860) & - & O & 0 & - & O \\
\hline centralis (Hagen, 1860) & 0 & 0 & 0 & $\bullet$ & O \\
\hline leucostigma (Fraser, 1933) & 0 & O & 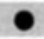 & ? & ○ \\
\hline tenax (Hagen, 1860) & $\mathrm{O}$ & $\mathrm{O}$ & $\mathrm{O}$ & - & $\mathrm{O}$ \\
\hline Prodasineura sita (Kirby, 1894) & 0 & 0 & 0 & - & $\mathrm{O}$ \\
\hline
\end{tabular}

Aeshnidae

\begin{tabular}{llllll}
\hline Anaciaeschna donaldi Fraser, 1922* & 0 & 0 & 0 & $\bullet$ & 0 \\
Anax indicus Lieftinck, 1942* & 0 & 0 & 0 & $\bullet$ & 0 \\
Gynacantha sp. indet. & 0 & 0 & 0 & $\bullet$ & 0
\end{tabular}

Gomphidae

\begin{tabular}{|c|c|c|c|c|c|}
\hline \\
\hline Anisogomphus solitaris Lieftinck, 1971 & - & - & - & 0 & 0 \\
\hline Burmagomphus pyramidalis sinuatus Fraser, 1933 & O & • & 0 & 0 & O \\
\hline Cyclogomphus gynostylus Fraser, 1926 & 0 & - & - & ○ & 0 \\
\hline Gomphidia pearsoni Fraser, 1933 & - & • & $\bullet$ & ○ & - \\
\hline Heliogomphus ceylonicus (Selys, 1878) & - & - & - & O & - \\
\hline lyratus Fraser, 1933 & 0 & - & - & - & - \\
\hline nietneri (Selys, 1878) & $\bullet$ & - & $\bullet$ & ○ & - \\
\hline walli Fraser, 1925 & O & $\bullet$ & $\bullet$ & $\bullet$ & $\bullet$ \\
\hline Macrogomphus annulatus keiseri Lieftinck, 1955 & - & - & $\bullet$ & ○ & \\
\hline lankanensis Fraser, 1933 & O & • & - & 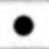 & • \\
\hline Megalogomphus ceylonicus (Laidlaw, 1922) & 0 & $\bullet$ & $\bullet$ & 0 & - \\
\hline Microgomphus wijaya Lieftinck, 1940 & 0 & $\bullet$ & $\bullet$ & $\mathrm{O}$ & $\bullet$ \\
\hline \multicolumn{6}{|l|}{ Corduliidae } \\
\hline Macromia flinti Lieftinck, 1977 & - & - & - & - & 0 \\
\hline zeylanica Fraser, 1927 & $\bullet$ & $\bullet$ & O & $\mathrm{O}$ & O \\
\hline \multicolumn{6}{|l|}{ Libellulidae } \\
\hline Cratilla lineata calverti Förster, 1903* & 0 & 0 & 0 & ○ & 0 \\
\hline Hydrobasileus croceus (Brauer, 1867)* & O & O & 0 & ○ & O \\
\hline Hylaeothemis fruhstorferi (Karsch, 1889) & 0 & 0 & $\bullet$ & ○ & - \\
\hline Indothemis carnatica (Fabricius, 1798)* & O & O & 0 & $\bullet$ & 0 \\
\hline limbata sita Campion, 1923* & 0 & 0 & 0 & 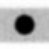 & O \\
\hline Lathrecista a. asiatica (Fabricius, 1798)* & O & O & 0 & $\bullet$ & O \\
\hline Macrodiplax cora (Kaup, 1867)* & 0 & $\mathrm{O}$ & 0 & ○ & $\mathrm{O}$ \\
\hline Onychothemis tonkinensis ceylanica Ris, $1912^{*}$ & 0 & 0 & 0 & $\bullet$ & O \\
\hline Orthetrum chrysis (Selys, 1891)* & 0 & 0 & 0 & 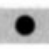 & 0 \\
\hline glaucum (Brauer, 1865)* & 0 & 0 & 0 & ○ & 0 \\
\hline luzonicum (Brauer, 1868)* & O & 0 & 0 & 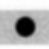 & 0 \\
\hline t. triangularis (Selys, 1878)* & O & 0 & $\mathrm{O}$ & ○ & $\mathrm{O}$ \\
\hline Palpopleura s. sexmaculata (Fabricius, 1787)* & 0 & 0 & 0 & ○ & 0 \\
\hline Rhyothemis triangularis Kirby, $1889^{*}$ & 0 & 0 & 0 & $\bullet$ & 0 \\
\hline Tetrathemis yerburii Kirby, 1894 & 0 & 0 & 0 & ○ & 0 \\
\hline Trithemis pallidinervis (Kirby, 1889)* & $\mathrm{O}$ & 0 & 0 & $\boldsymbol{0}$ & 0 \\
\hline
\end{tabular}


It is obvious that at present we know very little about the Odonata of Sri Lanka. There is practically no relevant information on the biology and ecology of endemic representatives. Also our knowledge on taxonomy and distribution has great gaps.

\section{THREAT STATUS OF THE ODONATE FAUNA OF SRI LANKA}

Not a single odonate species from Sri Lanka is included in the global IUCN Red List of threatened species (IUCN 2003). So far only one species, viz Sinhalestes orientalis has been placed on the "prestigious" world list of Odonata taxa to which special attention should be devoted in the following years (Moore 1997).

Unfortunately there are many additional ones which would deserve such status and should be declared as priority species for future investigations. This is imperative since the endemic odonate fauna of Sri Lanka is very endangered and some very interesting taxa are threatened with extinction.

The main reason for this is rapid destruction of primary rainforest, which has grown in last decades to a nature catastrophe. In the middle of 20th century more than $50 \%$ of Sri Lanka was covered with forest but only thirty years later the percentage has fallen to around $20 \%$. Impoundment, extraction for irrigation and careless pollution of rivers and streams, together with other pressures on flowing waters, have brought mostly endemic species to or even over the brink of extinction. Factors as high population growth followed by urbanisation and acute shortage of land - Sri Lanka has nearly 19 million inhabitants and a population density over 270 people per $\mathrm{km}^{2}-$, mining, soil erosion and environment pollution result in additional habitat loss and affect fauna and flora both directly and indirectly. It may look surprising but around $12 \%$ of the island is within different forms of protected areas, ranging from biosphere reserves and national parks, nature reserves, forest reserves, wildlife sanctuaries etc. Unfortunately, there is a complete lack of systematically gathered information on the odonate fauna of existing protected areas in Sri Lanka and not a single professional study on this topic has ever been made. In this situation we can only guess to which extent the existing protected areas really ensure the long-term conservation of Odonata.

Despite the fact that the proportion of protected areas in Sri Lanka is relatively high they are mainly located in the lowlands of Dry zone because of the historically strong attachment of official nature conservation towards elephants, leopards and other big animals. According to the hereto collected data, only a small proportion of endemic odonate taxa inhabit Dry zone forests as well as lowland rivers and numerous water tanks in this areas. The speculation that some endemic species

Comments on Table 1: There are additional species, whose occurrence on Sri Lanka is very poorly known but are elsewhere not rare. In this category following species could be included: Agriocnemis femina femina (Brauer, 1868), Anax ephippiger (Burmeister, 1839), Aethriamanta b. brevipennis (Rambur, 1842) and Zyxomma petiolatum Rambur, 1842. 
may already be extinct and that many small and isolated Odonata populations are probably on the brink of disappearance is unfortunately very close to reality. In addition, many protected areas are too small for long term survival of endangered species or degraded to the point where they do not harbour natural biodiversity. Even more problematic is the neglection of exceptionally rich fauna and flora of remaining patches of Wet-zone rain forests and their very incomplete inclusion in the protected areas system.

Only recently the nature protection agencies and institutions in Sri Lanka started to recognize odonates as an important part of island's biodiversity. As far as nature protection law is concerned not a single odonate species is mentioned in official "Fauna and Flora Protection Ordinance". On the other hand, in "The 1999 list of threatened fauna and flora of Sri Lanka" (IUCN Sri Lanka 2000), altogether 50 Odonata species are listed as 'threatened' (TR), 20 as 'highly threatened' (HT) and four as 'data deficient' (DD). More or less the same data are presented also in "A comparison of the conservation and legal status of the fauna and flora of Sri Lanka" (IUCN Sri Lanka 2003). Unfortunately, the only basis for the mentioned evaluation of the threat status has been the book by Fonseka (2000), which is not the best source for such task, especially for the non-odonatologist. Despite numerous deficiencies in listing and ranking of single odonate taxa, the general message was stressed quite correctly: the odonate fauna of Sri Lanka with its numerous endemic representatives is very endangered.

In Table 2 an attempt to assess the threat status of the odonate fauna of Sri Lanka has been made. The list of endangered species comprises 47 exclusively endemic taxa, among them also four recently discovered, yet undescribed species. This

Table 2. Endangered endemic odonate species found in Sri Lanka. DD: data deficient; RR: range restricted; IC: identity of species needs clarification; A: action recommended, because of habitat destruction.

\section{Family/species}

DD RR IC A Distribution / habitat and notes

Chlorocyphidae
$\begin{aligned} & \text { Libellago finalis (Hagen, 1869) } \\ & \text { Lestidae }\end{aligned}$
Indolestes divisus (Hagen, 1862)
Sinhalestes orientalis (Hagen, 1862)

Coenagrionidae

\begin{tabular}{|lll}
\hline Agriocnemis cf. femina (Brauer, 1868) & Rare species of doubtful taxonomic \\
Archibasis sp. nov. & position (see Bedjanič 2002a) \\
& Rivulets in the mid-hill primary rainforest \\
and surrounding less disturbed areas. & Rare species, discovered in 2001, \\
awaits description
\end{tabular}

Mortonagrion ceylonicum Lieftinck, 1971 - $\quad$ Not found since description 


\section{Family/species}

DD RR IC A Distribution / habitat and notes

Platystictidae

\begin{tabular}{|c|c|c|c|c|}
\hline Drepanosticta adami (Fraser, 1933) & $\bullet$ & - 0 & $\bullet$ & \\
\hline austeni Lieftinck, 1940 & $\bullet$ & $\bullet$ & $\bullet$ & Not found since description \\
\hline brincki Lieftinck, 1971 & $\bullet$ & $\bullet$ & $\bullet$ & \\
\hline digna (Selys, 1860) & $\bullet$ & $\bullet$ & $\bullet$ & \\
\hline fraseri Lieftinck, 1955 & $\bullet$ & $\bullet$ & $\bullet$ & Small streams and springs in rainforest \\
\hline hilaris (Hagen, 1860) & $\bullet$ & $\bullet$ & $\bullet$ & Not found since description \\
\hline lankanensis (Fraser, 1931) & $\bullet$ & $\bullet$ & $\bullet$ & \\
\hline montana (Hagen, 1860) & $\bullet$ & $\bullet$ & $\bullet$ & Not found since description \\
\hline nietneri (Fraser, 1931) & $\bullet$ & $\bullet$ & $\bullet$ & \\
\hline sinhalensis Lieftinck, 1971 & $\bullet$ & $\bullet$ & $\bullet$ & \\
\hline starmuehlneri St. Quentin, 1972 & $\bullet$ & $\bullet$ & $\bullet$ & \\
\hline submontana (Fraser, 1933) & $\bullet$ & $\bullet$ & • & Not found since description \\
\hline subtropica (Fraser, 1933) & - & $\bullet$ & $\bullet$ & \\
\hline tropica (Hagen, 1860) & $\bullet$ & $\bullet$ & $\bullet$ & $\begin{array}{l}\text { Small streams in dense montane forests } \\
\text { of mountain regions }\end{array}$ \\
\hline walli (Fraser, 1931) & - & $\bullet$ & $\bullet$ & \\
\hline sp. nov. A & $\bullet$ & $\bullet$ & $\bullet$ & $\begin{array}{l}\text { Streams in mid-hill primary rainforest } \\
\text { Rare species, discovered in 2003, seems } \\
\text { not to have near allies and awaits } \\
\text { description }\end{array}$ \\
\hline sp. nov. B & $\bullet$ & $\bullet$ & $\bullet$ & $\begin{array}{l}\text { Streams in mid-hill primary rainforest } \\
\text { Rare species, discovered in } 2003 \text {, seems } \\
\text { not to have near allies and awaits } \\
\text { description }\end{array}$ \\
\hline Platysticta apicalis Kirby, 1894 & $\bullet$ & - 0 & • & $\begin{array}{l}\text { Streams and rivulets in the mid-hill } \\
\text { primary rainforest and surrounding less } \\
\text { disturbed areas }\end{array}$ \\
\hline maculata Hagen, 1860 & $\bullet$ & - 0 & $\bullet$ & $\begin{array}{l}\text { Streams and rivulets in the mid-hill } \\
\text { primary rainforest and surrounding less } \\
\text { disturbed areas }\end{array}$ \\
\hline \multicolumn{5}{|l|}{ Protoneuridae } \\
\hline Disparoneura ramajana Lieftinck, 1971 & $\bullet$ & $\bullet$ & $\bullet$ & $\begin{array}{l}\text { Dense montane forest of mountain } \\
\text { regions. Not found since description }\end{array}$ \\
\hline Elattoneura bigemmata Lieftinck, 1971 & $\bullet$ & - 0 & $\bullet$ & $\begin{array}{l}\text { Streams and rivers in the lowland to } \\
\text { midhill primary rainforest and some } \\
\text { surrounding less disturbed areas }\end{array}$ \\
\hline caesia (Hagen, 1860) & $\bullet$ & - 0 & - & Streams in mid-hill primary rainforest. \\
\hline leucostigma (Fraser, 1933) & $\bullet$ & - 0 & $\bullet$ & $\begin{array}{l}\text { Small streams in dense montane forests } \\
\text { of mountain regions } \\
\text { Not found since description }\end{array}$ \\
\hline tenax (Hagen, 1860) & $\bullet$ & - 0 & $\bullet$ & $\begin{array}{l}\text { Streams in the mid-hill primary rain- } \\
\text { forest and surrounding less disturbed } \\
\text { areas }\end{array}$ \\
\hline
\end{tabular}


Gomphidae

\begin{tabular}{|c|c|c|c|c|c|}
\hline Anisogomphus solitaris Lieftinck, 1971 & $\bullet$ & $\bullet$ & $\bullet$ & • & $\begin{array}{l}\text { Not found since description. Taxonomic } \\
\text { position questionable, no near allies } \\
\text { Due to the considerable deviation in } \\
\text { adult and larval characters the species } \\
\text { most probably may belong to a new } \\
\text { genus (Lieftinck, 1971) }\end{array}$ \\
\hline Burmagomphus pyramidalis sinuatus Fraser, 1933 & $\bullet$ & $\bullet$ & O & $\bullet$ & \\
\hline Cyclogomphus gynostylus Fraser, 1926 & $\bullet$ & $\bullet$ & 0 & $\bullet$ & $\begin{array}{l}\text { Streams and rivers in the mid-hills to } \\
\text { lowlands. Taxonomicaly isolated, no } \\
\text { near allies }\end{array}$ \\
\hline Gomphidia pearsoni Fraser, 1933 & $\bullet$ & $\bullet$ & O & $\bullet$ & $\begin{array}{l}\text { Pools of moderately fast to slow flowing } \\
\text { streams and rivers in the mid-hill primary } \\
\text { rainforest and some surrounding less } \\
\text { disturbed areas }\end{array}$ \\
\hline Heliogomphus ceylonicus (Selys, 1878) & $\bullet$ & $\bullet$ & - & $\bullet$ & $\begin{array}{l}\text { Not found since description } \\
\text { Taxonomic position is doubtful }\end{array}$ \\
\hline lyratus Fraser, 1933 & $\bullet$ & $\bullet$ & O & $\bullet$ & Not found since description \\
\hline nietneri (Selys, 1878) & $\bullet$ & $\bullet$ & 0 & $\bullet$ & Not found since description \\
\hline walli Fraser, 1925 & $\bullet$ & $\bullet$ & O & $\bullet$ & $\begin{array}{l}\text { Streams and rivers with waterfalls in the } \\
\text { mid-hills }\end{array}$ \\
\hline
\end{tabular}

\begin{tabular}{|c|c|c|}
\hline Macrogomphus annulatus keiseri Lieftinck, 1955 & - 0 & - \\
\hline lankanensis Fraser, 1933 & - $\bullet 0$ & $\bullet$ \\
\hline Megalogomphus ceylonicus (Laidlaw, 1922) & - 0 & $\begin{array}{l}\text { Streams and rivers in the lowland to mid- } \\
\text { hill primary rainforest and some surroun- } \\
\text { ding less disturbed areas }\end{array}$ \\
\hline
\end{tabular}

Microgomphus wijaya Lieftinck, 1940

Corduliidae

Macromia flinti Lieftinck, 1977 zeylanica Fraser, 1927

Macromidia sp. nov.

Libellulidae

Hylaeothemis fruhstorferi (Karsch, 1889)

Tetrathemis yerburii Kirby, 1894
- 0 - Not found since description

- $\quad$ - Streams and rivers with rich surrounding vegetation in the mid-hill areas

- - - Rare species discovered in 2001 and related to M. donaldi (Fraser, 1924) from South India, awaits description

Not found in last 50 years. Related to H. indica Fraser, 1946

- Vegetation along streams and rivers in the mid-hill rainforest. Unusual biology, characteristic oviposition for the genus 
means, by other words, that more than $80 \%$ of the described endemic odonate taxa are threatened. Almost all endemic representatives of families Platystictidae, Protoneuridae, Gomphidae and Corduliidae are listed. The fact is alarming and definitely has global importance from the biodiversity conservation point of view. Evaluation of threat status of individual species is mainly based on published data. New unpublished data collected by me in 2001 and 2003, as well as unpublished results of intensive collecting carried out in the 1970s by the staff of Smithsonian Institution from USA (M.A. Lieftinck in litt.; J. van Tol pers. comm.) were used in this respect as well. Since the odonate fauna of Sri Lanka is insufficiently known, many of the listed species in Table 2 could automatically be marked as 'data deficient'. From the global point of view, all can also be marked as 'range restricted' species. Their known occurrence is limited almost exclusively to few isolated localities in the Wet and Intermediate zone of Sri Lanka. As far as taxonomy is concerned a revision of the exclusively endemic family Platystictidae with remarkable species radiation is urgently needed. Detailed revision of this family done by Fraser (1933a) has been supplemented by subsequent workers with description of five species (Lieftinck 1940, 1955, 1971; St. Quentin 1972), and recently also some new material was collected by me. A preliminary analysis shows that some taxa of the family Platystictidae from Sri Lanka are still undescribed and others may fall into synonymy.

On the basis of literature data and available unpublished records the following endemic species are preliminary put in the IUCN categories 'extinct' (EX) and 'critically endangered' (CR): Sinhalestes orientalis, Drepanosticta adami, D. austeni, D. hilaris, D. montana, D. submontana, Elattoneura leucostigma, E. caesia, Disparoneura ramajana, Anisogomphus solitaris, Cyclogomphus gynostylus, Gomphidia pearsoni, Heliogomphus ceylonicus, H. lyratus, H. nietneri, Macrogomphus lankanensis, Microgomphus wijaya, Macromia flinti, Tetrathemis yerburii and Hylaeothemis frubstorferi. Herewith they are urgently proposed to be included on the IUCN list of globally endangered animals.

It should be stressed that this list is far from being complete and may only represent an incomplete top of the iceberg. Surely some additional endemic species listed in Table 2, as well as some undescribed taxa, are highly endangered and are at the brink of extinction.

\section{CONSERVATION PRIORITIES AND RECOMMENDATIONS}

Effective nature conservation measures in declared protected areas as well as establishment of new protected areas in the Wet zone are of biggest importance and the only way to insure the long-term preservation of a rich endemic fauna and flora of Sri Lanka, including Odonata. Since natural vegetation and habitats are already so disturbed and fragmented, the focus should be set on taking an effective action to stop further encroachment on the wet zone rainforests and establishment of smaller protected areas and corridors between them. Only such "network" could ensure long-term preservation of endemic fauna and flora.

As far as Odonata are concerned, the basic information on biology and distribution of endemic species is still very poor. Therefore it is impossible to suggest any 
"single-species-oriented" conservation measures yet. In order to improve our knowledge on the odonate fauna of Sri Lanka special attention in the future should be devoted to projects dealing with taxonomy of larval forms and adults, in connection with serious faunistic mapping and research on the biology of selected odonate species (see below). Only in this way we will be able to effectively asses their conservation status, suggest appropriate conservation measures for the key species as well as to recognise and promote the huge importance of the odonate fauna of Sri Lanka for world science and conservation of biodiversity. Fortunately very high diversity of fauna and flora, especially the number of taxa confined to the island, has already been recognized and there are good reasons to name Sri Lanka one of the "hot-spots" of South and South-east Asia (Mittermeier et al. 2000). In addition, Sri Lankan Moist Forests (Ecoregion 21) and South-western Sri Lanka Rivers and Streams (Ecoregion 172) are included in the prestigious WWF's global 200 list of the earth's most biologically outstanding habitats (Olson et al. 2000).

\section{RESEARCH PRIOTITIES AND RECOMMENDATIONS}

The odonate fauna of Sri Lanka is very interesting but insufficiently known. Knowledge on distribution, biology and taxonomy is very poor, especially regarding larval forms. Due to the habitat destruction (mainly primary tropical rainforest) the odonate fauna of Sri Lanka is also very endangered - some very interesting or/and endemic taxa are threatened with extinction or are probably already extinct. According to this facts the main Odonata research priorities are as follows:

Special attention in the future should be devoted to the work dealing with taxonomy of larval forms and adults. Expert taxonomic knowledge should be focused especially on description of larval forms and exuviae.

Serious faunistic mapping should cover the whole island. In order to get an overview of conservation status of less widespread and highly endangered endemic species, the research should be focused on protected areas and other still preserved areas without nature conservation status.

Simultaneously also the research of biology of selected species and research of seasonal phenology of adult odonate species should start.

All existing odonatological data (museum collections and literature) should be put in an odonatological database, which would enable overview of present knowledge for each species and generate outputs such as distribution maps etc.

To carry out the suggested measures successfully, some basic conditions have to be fulfilled on local and international level. Above all, mutual cooperation with appropriate nature conservation institutions and experts in Sri Lanka should be built and joint projects should be prepared. As a part of these, a small team of local scientists or students should be trained in Odonata research.

For serious scientific faunistic work, which is inevitably connected with the capture of Odonata and building up museum collections, legal permission has to be issued by appropriate nature conservation authority. It has to be stressed that the capture of 
voucher material is substantial for serious odonatological scientific work. In the contrary to the general belief, it does not influence the species' conservation status in any way and is absolutely necessary in order to get reliable and verifiable data. In addition, Odonata are not commercially interesting in the sense of "entomological resale", therefore serious scientific collecting is not problematic from any nature conservation perspective. In any case, a kind of mechanism should be developed, which would ensure easier obtaining of necessary permits for field work on one hand and on the other hand would control the field work in terms of collecting and submitting the results. The IUCN Species Survival Commission - Odonata Specialists Group could act as an important mediator in issuing recommendation based on references of the researcher and could also play an important role in the exchange and evaluation of results.

\section{CURRENT ODONATOLOGICAL AVTIVITIES AND FUTURE PERSPECTIVE}

In last years the interest on the odonate fauna of Sri Lanka has considerably grown. Herewith the book 'Dragonflies of Sri Lanka' (Fonseka 2000) greatly fulfilled its basic purpose. In addition, some popular articles on dragonflies, such as the one written for the widely read nature conservation magazine 'Sri Lanka nature' (De Silva Wijeyeratne 2001), definitely helped to stimulate this aspect. Based on my cooperation with local naturalists and sponsored by the leading Sri Lankan ecotouristic company Jetwing, a small photographic guide to the dragonflies of Sri Lanka has been published recently (De Silva Wijeyeratne et al. 2003). It comprises 88 photographs of 64 odonate species, including many interesting endemic representatives. Odonata photographs and short species descriptions will also form a part of the new popular 'Field guide to birds, butterflies and dragonflies of Sri Lanka', which is scheduled to be published in 2004 in Sinhala and English language. In the frame of activities of ecotouristic company Jetwing, also a special 'Dragonfly Research Project' is being developed, details of which can be found on the Internet <www.jetwingeco.com>. The already mentioned book of T. de Fonseka and recently published photographic field guides will definitely encourage more foreign odonatists to travel to the island and make their research here.

Since my first field trip to the island in $1995 \mathrm{I}$ am involved in the studies of the odonate fauna of Sri Lanka. Up to now a comprehensive graduation thesis (Bedjanič 1998), as well as some articles were published on the topic (Bedjanič 1999, 2000, 2001, 2002a; Bedjanič \& Şalamun 2002). Recently, a small booklet 'Dragonflies of Sri Lanka in colour' has been privately published as a draft of a future photographic manual to the odonate fauna of the island (Bedjanič 2002b). In absence of official permits the fieldwork has unfortunately mainly been limited to the non-protected areas, but nevertheless gave very good results. More than 50 localities were visited and more than 70 species were recorded both in 2001 and 2003. Among the recorded species there are some very interesting and even new taxa as well as many so far unknown larval forms. The extent of the latter is surprisingly high, so it will be possible to describe the last larval instars of more than a dozen endemic species. In the almost exclusively endemic family Gomphidae, for 
instance, this would mean that only three or four of the currently known species will be without description of the final larval instar. This opens many new possibilities, especially in mapping and studying of larval biology and habitat requirements of selected species.

In conclusion it is worth stressing again that the above analysis is almost exclusively based on published records only. My still unpublished data as well as the unpublished results of the above mentioned investigation of the staff of Smithsonian Institution from USA were only used for the compilation of the list of the most endangered odonate species in Sri Lanka (Table 2). Since not even all existing records were collected yet, one of the first goals in future Odonata research will be the examination of all available museum collections and gathering of individual faunistic data into a database for a 'Distributional atlas of the dragonflies of Sri Lanka'. In this respect the collection in the Smithsonian Institution is only one part of the work, which will have to be continued at least in London, Leiden and Colombo Natural History Museums. With the better knowledge of larval forms also older larval collections in Lund and Vienna Museum will give many new information, not only on distribution of the species but also on their biology. The next very important step will be the inventarisation of the odonate fauna in all protected areas. Especially reserves and sanctuaries in the Wet and Intermediate zone will surely bring many new Odonata taxa to the light, not to mention the crucial nature conservation overview, namely, to which extent the existing protected areas really ensure the long-term preservation of the extremely interesting endemic odonate fauna.

\section{ACKNOWLEDGEMENTS}

For the constant support and help with literature the author is thankful to Bastiaan Kiauta (Bilthoven, The Netherlands). Jan van Tol (Leiden, The Netherlands) enabled the work in the odonatological collection of the National Natuurhistorisch Museum in Leiden, allowed the copying of a part of Lieftinck's correspondence and helped in various other aspects. Especially encouraging were fruitful discussions with the late Terence de Fonseka (London, UK), who also greatly helped with literature. Due to help and enthusiasm of Gehan De Silva Wijeyeratne (Colombo, Sri Lanka) the work on Sri Lanka's 'Dragonfly Research Project' continues in various ways. Ali Calamun (Koper, Slovenia) and Mojca Bedjanic (Slovenska Bistrica, Slovenia) rendered pleasant company and helpful hand during the fieldwork in Sri Lanka.

\section{REFERENCES}

Bedjanič, M., 1998. An attempt of the analysis of the dragonfly fauna of Sri Lanka (Insecta: Odonata). Graduation Thesis, University of Ljubljana. [In Slovenian; English title and abstractl.

Bedjanič, M., 1999. The "dry season" aspect of the odonate fauna of Sri Lanka. Abstracts of Papers presented at the Second Odonatological Symposium of the Alps-Adriatic Regional Community, Deutsch-Wagram (near Vienna), Austria, July 14-18, 1996. Anax 2: 45. 
Bedjanič, M., 2000. Description of the last larval instar of Epophthalmia vittata cyanocephala Hagen, 1867 (Anisoptera: Corduliidae). Odonatologica 29: 57-61.

Bedjanič, M., 2001. Erforschungsstand der Libellenfauna von Sri Lanka. Abstracts of Papers and Posters Presented on the XVII. SIEEC Symposium, Radenci, Slovenia, 20.V.-26.V.2001, Radenci, pp. 9-10.

Bedjanič, M., 2002a. Dragonflies collected in Sri Lanka during January and February 1995 (Odonata). Opuscula Zoologica Fluminensia 205: 1-22

Bedjanič, M., 2002b. Dragonflies of Sri Lanka in colour: first draft version 2002. Bedjanič, Fram.

Bedjanič, M. \& A. Şalamun, 2002. Additional notes on the last larval instar of Epophtalmia vittata cyanocephala Hagen, 1867 from Sri Lanka (Odonata: Corduliidae).

Opuscula Zoologica Fluminensia 204: 1-6

De Silva Wijeyeratne, G., 2001. Dragonflies and damselflies for beginners.

Sri Lanka Nature 3: 20-24.

De Silva Wijeyeratne, G., M. Bedjanic \& K. Coniff, 2003. Dragonflies of Sri Lanka. Jetwing Research Initiative, Colombo.

Fonseka, T. de, 2000. Dragonflies of Sri Lanka. Wildlife Heritage Trust, Colombo.

Fraser, F.C., 1933a. The Platystictas of Ceylon (Order Odonata).

Ceylon Journal of Science (B) 17: 201-224.

Fraser, F.C., 1933b. The Gomphines of Ceylon (Order Odonata). Ceylon Journal of Science (B) 18: 19-36.

Fraser, F.C., 1933c. The Fauna of British India including Ceylon and Burma: Odonata: Vol. I. Taylor \& Francis, London.

Fraser, F.C., 1934. The Fauna of British India including Ceylon and Burma: Odonata: Vol. II. Taylor \& Francis, London.

Fraser, F.C., 1936. The Fauna of British India including Ceylon and Burma: Odonata: Vol. III. Taylor \& Francis, London.

IUCN, 2003. 2003 IUCN Red List of threatened species. <www.redlist.org/>.

IUCN Sri Lanka, 2000. The 1999 list of threatened fauna and flora of Sri Lanka. IUCN Sri Lanka, Colombo.

IUCN Sri Lanka, 2003. A comparison of the conservation and legal status of the fauna and flora of Sri Lanka. IUCN Sri Lanka, Colombo.

Kirby, W.F., 1891. On some Neuroptera Odonata (dragon-flies) collected by Mr. E.E. Green in Ceylon. Proceedings of the Zoological Society of London 1891: 203-206, pl. 20.

Kirby, W.F., 1894. Catalogue of the described Neuroptera Odonata (dragonflies) of Ceylon, with description of new species. Zoological Journal of the Linnean Society 24: 545-566, pls 41-42.

Kirby, W.F., 1905. List of a small collection of Odonata (dragonflies) from Ceylon, collected by Mr. E. Ernest Green, with notes on the genus Zygonidia and its allies, and descriptions of new species of Zygonidia, Kirb., and Onychothemis, Brauer, from Ceylon and Tonkin. Annals and Magazine of Natural History (VII) 15: 270-278.

Laidlaw, F.F., 1924. A catalogue of the dragonflies (Odonata) recorded from Ceylon, based on material collected by Mr. E.E. Green, with description of a new species. Spolia Zeylanica 12: 335-374.

Laidlaw, F. F., 1951. A note on the derivation of the odonate fauna of the Island of Ceylon. Entomological News 62: 77-83.

Lieftinck, M.A., 1940. On some Odonata collected in Ceylon, with description of new species and larvae. Ceylon Journal of Science (B) 22: 79-117. 
Lieftinck, M.A., 1955. Synopsis of the dragonflies (Odonata) of Ceylon. Zoölogische Mededelingen, Leiden 34: 67-87.

Lieftinck, M.A., 1971. Odonata from Ceylon. Entomologica Scandinavica, Supplement 1: 188-207.

Mittermeier, R.A., N. Myers \& C.G. Mittermeier, 2000. Hotspots: earth's biologically richest and most endangered terrestrial ecoregions. CEMEX Conservation International, Mexico City.

Moore, N.W., 1997. Dragonflies - status survey and conservation action plan.

IUCN/SSC Odonata Specialist Group. IUCN, Gland \& Cambridge.

Olson, D.M., E. Dinerstein, R. Abell, T. Allnutt, C. Carpenter, L. McClenachan, J. D'Amico, P. Hurley, K. Kassem, H. Strand, M. Taye \& M. Thieme, 2000. The Global 200: a representation approach to conserving the earth's distinctive ecoregions. Conservation Science Program, World Wildlife Fund-US, Washington. <www.panda.org >.

St. Quentin, D., 1972. Results of the Austrian Ceylonese Hydrobiological Mission 1970 of the 1st Zoological Institute of the University of Vienna (Austria) and the Department of Zoology of the Vidyalankara University of Ceylon, Kelaniya. Part VI: a new Drepanosticta from Ceylon (Order: Odonata; Insecta). Bulletin of the Fisheries Research Station, Sri Lanka 23: 137-139.

St. Quentin, D., 1973. Results of the Austrian Ceylonese Hydrobiological Mission 1970 of the 1st Zoological Institute of the University of Vienna (Austria) and the Department of Zoology of the Vidyalankara University of Ceylon, Kelaniya. Part XII: contributions to the ecology of the larvae of some Odonata from Ceylon. Bulletin of the Fisheries Research Station, Sri Lanka 24: 113-124. 